\title{
SNPs in toll-like receptor $(T L R)$ genes as new genetic alterations associated with congenital toxoplasmosis?
}

\author{
W. Wujcicka • J. Wilczyński • D. Nowakowska
}

Received: 5 October 2012 / Accepted: 8 October 2012/Published online: 17 November 2012

(C) The Author(s) 2012. This article is published with open access at Springerlink.com

\begin{abstract}
Nearly $40 \%$ of pregnant women are infected with Toxoplasma gondii. Primary infections in pregnant women result, in approximately $30-50 \%$ of patients, in transmission of $T$. gondii through the placenta to the fetus and then in congenital infections with severe, sometimes fatal course. Studies still do not provide sufficient data on the genetic bases of the immunity in fetuses, newborns, and infants with congenital toxoplasmosis. Previous research showed the contribution of toll-like receptors (TLRs) to non-specific immunity against $T$. gondii invasion, observed in $T$. gondii-infected animals, especially mice. So far, the activity of TLRs in defense against $T$. gondii infections was observed particularly for TLR2, TLR4, and TLR9 molecules. Differential TLR activity associates with both cell types, including a variety of placental cells and stage of pregnancy. Several singlenucleotide polymorphisms (SNPs) residing in three genes encoding these receptors were reported as significant genetic modifications of TLRs associated with different pregnancy disorders. Despite those data, genetic alterations of TLRs which have contributed to innate immune response against $T$. gondii infections are still not precisely described. In this article, we present reasons for the research of the plausible role of SNPs residing in TLR2, TLR4, and TLR9 genes in congenital toxoplasmosis development.
\end{abstract}

\section{TLRs contribute to Toxoplasma gondii infections}

Toxoplasmosis is one of the most frequent pregnancy infections transmitted from mother to child and the major cause

\footnotetext{
W. Wujcicka J. Wilczyński $\cdot$ D. Nowakowska $(\triangle)$

Department of Fetal-Maternal Medicine and Gynecology,

Polish Mother's Memorial Hospital Research Institute,

281/289 Rzgowska Street,

Lodz 93-338, Poland

e-mail: dnowakowska@yahoo.com
}

of perinatal morbidity and mortality [1-3]. In Poland, nearly $40 \%$ of pregnant women are infected with Toxoplasma gondii $[4,5]$. Meiosis occurred in oocysts of $T$. gondii and resulted in the production of many different genotypes of parasitic sporozoites; however, three predominant distinct clonal lines (virulent strain I and non-virulent strains II and III) were found in Europe and North America [1, 6, 7]. Primary infections are dangerous in pregnant women, occurring usually asymptomatically, resulting, in approximately $30-50 \%$ of patients, in transmission of $T$. gondii through the placenta to the fetus. As a result, these infections cause, in the fetuses and newborns, with immature immune systems, congenital infections with very severe, sometimes fatal course $[3,5,8]$. So far, extensive investigations aimed to describe mechanisms of congenital infections and related immune responses. However, current studies do not provide sufficient data on the associated alterations and genetic background of the innate immunity to $T$. gondii occurring in newborns and infants congenitally infected with this parasite. Three of ten human toll-like receptors (TLRs), TLR2, TLR4, and TLR9, have been reported to play roles in the recognition of $T$. gondii, course of infections with this parasite, and also in pregnancy progression and disorders.

So far, studies clearly confirmed the essential role of TLR/MyD88 signaling in non-specific antimicrobial immune response to $T$. gondii infections. Many previous works reported the crucial role of IL- 12 and of IFN- $\gamma$, the major regulators of IFN- $\gamma$ production, by NK and T cells and cellmediated immunity to $T$. gondii, respectively $([9,10]$, reviewed in $[11,12])$. The high expression levels of these two cytokines are stimulated after primary infection with $T$. gondii [11]. In mice, TLR11 was reported as the main regulator of IL-12 production following $T$. gondii infection ([11, 13], reviewed in [14]). However, TLR11 in humans is only a non-functional pseudogene $[11,15]$. Hence, in this study, we described the role of other receptors from the TLR 
family in the defense against $T$. gondii. We suppose that genetic modifications, especially of TLR2, TLR4, and TLR9, might play a plausible role in congenital toxoplasmosis development. To argue the major role of TLRs in innate immune response to $T$. gondii, we described the most recent studies showing their involvement in immunity to this parasite. Figure 1 illustrates the activities and interactions of TLRs and other molecules reported to be involved in the immune response to $T$. gondii infection.

The latest study performed to describe the method of action of lipoxin- and L-kynurenine-induced SOCS2 in the pro-inflammatory response during infection also with $T$. gondii showed the engagement of both mediators in the inhibition of TLR/MyD88, TLR/TRIF, IL-1R/MyD88, and CD40/CD154 signaling pathways [16] (Fig. 1). Other studies reported that TLR response to $T$. gondii is promoted by the $\zeta$ isoform of the diacylglycerol (DAG) kinases family (DGK $\zeta)$, expressed in macrophages $(\mathrm{M} \Phi)$ and dendritic cells (DC) via a pathway involving the inhibition of PI3K [17] (Fig. 1). DGK $\zeta$ deficiency resulted in impaired IL12 and TNF- $\alpha$ production after in vitro and in vivo TLR stimulation, elevated resistance to endotoxin shock, and increased susceptibility to $T$. gondii infection [17]. Studies which aimed to describe the role of DC in the immune response to $T$. gondii showed that mice with targeted inactivation of MyD88 in these cells, but not in macrophages or neutrophils, were highly susceptible to the $T$. gondii infection [18]. Subsequent results indicated the crucial role of TLR recognition by DC in the creation of a rapid type 1 innate immunity to $T$. gondii and to prevent acute mortality [18]. Murine CD11c+Gr-1+ DC infected with $T$. gondii, in contrast with non-infected cells, had no ability for ex vivo TLR stimulation [19]. Then, the observed results suggested that plasmacytoid DCs (pDCs) were utilized by $T$. gondii as Trojan horses in the early infection, with suppressed cytokine effector function, and exploited to disseminate the parasite within the host [19]. Earlier studies also reported the important cell-intrinsic role of MyD88 in the activation of neutrophils, macrophages, $\mathrm{DC}$, and $\mathrm{T}$ cells during immunity to $T$. gondii $[11,12]$. However, the function of MyD88 in neutrophils, macrophages, and monocytes has to be determined in detail. MyD88 $8^{-/-}$mice orally infected with $T$. gondii failed to control the parasite and succumbed within 2 weeks of infection, but the i.p. vaccinations of these mice with avirulent $T$. gondii uracil auxotroph induced strong IFN responses and protective immunity to the invasion of highvirulence $T$. gondii strains [20]. Hence, the results of this study confirmed that MyD88 is required to control T. gondii infection, but the adaptive immunity might be induced without the involvement of TLR adaptor molecule [20].

As MyD88 might be activated by almost all TLRs except TLR3, recent investigations also aimed to identify particular receptors crucial for the initial recognition of $T$. gondii. One of the latest studies showed that single nucleotide-sensing TLR3, TLR7, and TLR9 have no function in controlling the initial activation of innate immune response and host resistance to $T$. gondii infection in the $3 \mathrm{~d}$ mice with a nonfunctional UNC93B1, a critical mediator of the translocation of the three investigated TLRs from ER to endolysosomes [21] (Fig. 1). However, 3d mice were extremely susceptible to infection with $T$. gondii. Therefore, the likely combined action of nucleotide-sensing TLR3, TLR7, and TLR9 in host defense against $T$. gondii was suggested [21].

Studies of 264 healthy Russian Karelian children performed to analyze the influence of the gene environment effect of T. gondii, Helicobacter pylori, CD14 $-159 \mathrm{C}>\mathrm{T}$, and TLR4 $+1896 \mathrm{~A}>\mathrm{G}$ polymorphisms on the total serum IgE showed no association between $T$. gondii or H. pylori seropositivity, or CD14 and TLR4 polymorphisms with IgE levels [22]. However, the constructed multiway analysis of variance (ANOVA) model showed the influence of CD14 -159 allele T and H. pylori antibodies status on the serum total IgE [22].

\section{The role of TLR2, TLR4, and TLR9 in Toxoplasma gondii infections}

Among TLR characteristics for human cells, the activity in sensing $T$. gondii was especially determined for TLR2, TLR4, and TLR9 molecules [23-26]. In the transcriptome-profiling study performed to identify genes synergistically up-regulated by IFN- $\gamma$ and TNF in macrophages, several proinflammatory cytokines and also TLR agonists were reported to stimulate increased expression of newly identified immunoresponsive gene 1 (IRG1) transcript [27]. The expression of IRG1 transcript was up-regulated after the stimulation of TLR2, TLR4, and TLR9 by LTA, lipopolysaccharide (LPS), and CpG, respectively. As IRG1 expression was not regulated by TLR3 stimulated by poly I:C, which is not signaled via MyD88, the molecule involved in the signaling of TLR2, TLR4, and TLR9, the MyD88 molecule, was suggested to be required for the induction of IRG1 [27] (Fig. 1). In other work, TLR2deficient mice infected with 300 cysts of $T$. gondii died within a period of 10 days; however, all of them survived when the parasite dose was lower [28]. In T. gondii infection cases, TLR2 participated in macrophages activation and regulation of parasite-induced NO production [28]. Another study showed that iNOS ${ }^{-/}$mice were able to control the acute $T$. gondii infection, in which additional effector mechanisms were possibly regulated by TLR2 [29]. This receptor was also reported to regulate the $T$. gondii-induced production of the neutrophil-attracting chemokine CCL2 [30]. Experiments with the vaccination of $T$. gondii-infected mice with $T$. gondii-derived heat shock protein 70 (T.g.HSP70) gene showed its involvement in DC activation and Th1 polarization observed 


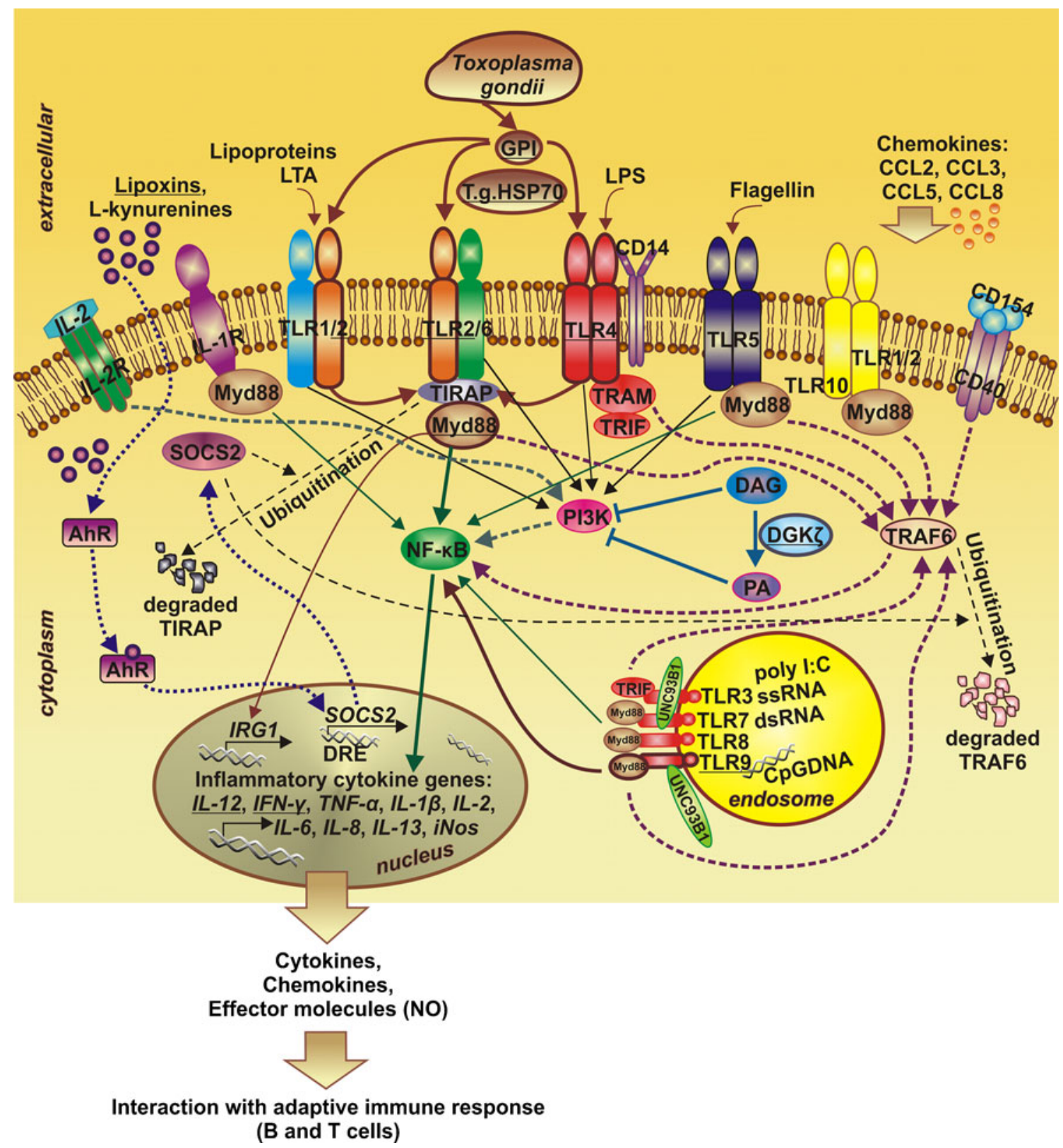

Fig. 1 Toll-like receptor (TLR) signaling pathways involved in immune response to Toxoplasma gondii infections. Molecules considered to be crucial during $T$. gondii infection are underlined and surrounded by a thick continuous line

at draining lymph nodes (dLN) from wild type and TLR2deficient mice, but not TLR4-deficient individuals with B6 background [31]. Early Th1 polarization was induced at the dLN of mice by the T.g.HSP70 gene vaccine through the TLR4/MyD88 signal pathway (Fig. 1). At an acute phase of toxoplasmosis, the T.g.HSP70 gene vaccine also limited the copy number of $T$. gondii in the mesenteric LN of WT, TLR2deficient, and TRIF-deficient mice, but for neither TLR4deficient nor MyD88-deficient mice, indicating the involvement of TLR4 in the vaccine effect at an acute phase of infection. What is more, TLR4 had activity in the determination of the $T$. gondii cyst number of the brain at a chronic phase of toxoplasmosis, observed also at 8 and 12 weeks postinfection [31]. TLR4-mediated macrophage activation was observed during T. gondii and Leishmania donovani infection, although this response was differentially regulated by progesterone via the glucocorticoid and progesterone receptors [23]. Another study showed that purified T. gondii glycosylphosphatidylinositols (GPI) triggered TLR4 signaling pathways as well [24]. Mice lacking both TLR2 and TLR4, but not TLR2 alone, had completely abrogated production of TNF in the response of $T$. gondii GPI [24]. However, mice deficient in TLR4 were only a little more susceptible to the $T$. gondii infection [24]. A significant role of TLR4 was reported in $T$. 
gondii infection observed in the small intestine [32]. TLR9deficient mice infected orally with $T$. gondii were relatively resistant to the ileitis and had reduced Th1 response to the parasite $[25,26]$. TLR9 deficiency in mice infected orally with T. gondii resulted in increased susceptibility to the infection and a $50 \%$ reduction in IFN- $\gamma$ production [26]. Then, the results proved that the TLR9 contribution coordinated both innate and adaptive immune response to $T$. gondii. However, the crucial indirect role in the stimulation of immunity to $T$. gondii is possibly characteristic for commensal gut bacteria rather than the parasite itself $[25,33]$.

\section{The activity of TLRs during pregnancy}

The expression of TLR genes was observed in immune and also in non-immune cells such as trophoblasts, decidual cells, and amniotic epithelium [34-36]. The expression profile of TLR was associated with cell types, stage of pregnancy, and response to microorganisms ([34, 36-38], reviewed in $[39,40])$. Studies performed for paraffin-embedded sections of endometrium and deciduas from first and second trimester elective terminations and third trimester normal deliveries showed alterations in the TLR4 expression levels between particular tissue samples [34]. Higher immunoreactivity of TLR 4 observed in decidual cells compared to interstitial trophoblasts suggested maternally derived cells as the main protectors against Gram-negative bacteria and other harmful signals from severe inflammation associated with or without infection. Particularly, significantly higher TLR4 levels were observed in decidual cells of the first and third trimester compared to second trimester basalis, suggesting that an enhanced inflammatory environment occurred at the maternal-fetal interface in the initial stages and end of pregnancy compared to mid-pregnancy [34]. In turn, another study showed the presence of TLR2 and TLR4 proteins expressions from the one-cell stage through the blastocyst stage during murine embryo development [41]. In trophoblast stem cells, the expression of TLR2 and TLR6 but not TLR1 or TLR4 was observed [41]. At the plasma membrane, the expression of only TLR2 molecules was determined. The limited expression of TLRs on trophoblast cells suggested that early trophoblasts might be less able to protect embryos against pathogenic agents compared to differentiated trophoblast cells [41]. The obtained results are consistent with outcomes of another study, which indicated that TLR4 expression and related IL-8 secretion that occurred after LPS stimulation might be assigned, rather, to leukocytes, as it was no longer observed in trophoblast fraction purified from leukocytes [42]. The expression of different antimicrobial peptides and proteins was suggested to be characteristic for various placental cells and resulted from the cooperation between leukocytes and cells of embryonic origin [42]. Functional screening tests of TLRs in human amniotic epithelial cells showed that the expression of TLR5, TLR6/2, and TLR4 occurred in these cells [35]. The activation of TLR5 and TLR6/2 stimulated both IL-6 and IL- 8 production and the NF-KB signaling pathway, whereas TLR4 activity was associated with reduced viability of analyzed cells and their apoptosis. Hence, differential immune response mediated via specific TLRs might even lead to preterm birth [35]. Other data suggested a contribution of TLR ligands to the direct activation of decidual NK cells and also NK cell lines observed in the presence of proinflammatory cytokines [43]. In human decidual mononuclear cells (DMNC), LPS, known as the TLR4 ligand, induced IFN- $\gamma$ and TNF- $\alpha$ production, from which the former was IL-2- and IL-12-dependent, while the latter was independent [43]. Hence, further studies were suggested to be necessary to determine the mechanisms driving the synergistic effect of TLR and cytokine signaling [43]. Research of cultured cells of term placenta, including cytotrophoblast- and syncytiotrophoblast-rich cells, showed the expression of TLR2, TLR3,TLR4, TLR5, TLR6, and $T L R 9$ genes [36]. In first-trimester primary trophoblasts and trophoblast cell lines, the expression of TLR1, TLR2, TLR3, and TLR4, but not TLR6, was observed [37, 44]. However, the last gene was expressed in third-trimester trophoblasts, which suggested its regulation in a temporal manner [36, 37]. The TLR4 expression level was higher in the term compared to the first-trimester placentas [45]. Placentas from early pregnancy were reported as being less responsive to pathogen agents than term tissues. TLR2 and TLR4 transcripts were identified in villous cytotrophoblast and extravillous trophoblast, but not in syncytiotrophoblasts in the first-trimester placenta [37]. It also suggested the regulation of TLR in a spatial manner. Then, it seemed that pathogens might be dangerous to the fetus only when the TLR-negative outer trophoblast layer is interrupted and infecting agents enter either the placental villous or the decidual compartments [37, 44]. The level of TLR1TLR10 transcripts was also investigated in term human placentas collected in the absence of labor (elective cesarean sections; ECS) and after the completion of labor (normal vaginal delivery; NVD) [38]. TLR1-TLR10 transcripts were observed in all placentas; however, NVD tissues produced higher levels of TNFA in response to TLR4 (LPS) and to TLR7/8 agonist (resiquimod) than ECS placenta explants. Significantly elevated levels of TLR2 and TLR5 correlated with labor. Hence, this data suggested the role of TLR in parturition [38]. Studies of mRNA expressions of TLR2, TLR3, TLR4, and TLR9 in the uterus, cervix, and placenta of non-pregnant and across gestation CD-1 mice showed significantly elevated levels in pregnant uterine and cervical tissues [46]. The differential levels of TLR mRNA expressions were observed between the uterus, cervix, and 
placenta with significantly down-regulated TLR4 gene expression in the placenta [46]. The data suggested that the innate immune system was an active and dynamic system during gestation, with the altered expression of TLRs at the maternal-fetal interface playing a crucial role in the pathogenesis of adverse pregnancy outcomes.

Despite data confirming the involvement of TLR2, TLR4, and TLR9 receptors in the non-specific immunity to $T$. gondii, their contribution to toxoplasmosis development, and function within pregnancy, detailed mechanisms driving the activity of these receptors in $T$. gondii congenital infections are not known. So far, previous research showed the participation of several single-nucleotide polymorphisms (SNPs) of TLR2, TLR4, and TLR9 in various diseases and pregnancy disorders [47-49].

\section{SNPs in the TLR2 gene associated with pregnancy disorders}

In a group of 200 cord blood samples obtained from 72 atopic and 128 non-atopic mothers, 12 SNPs located in TLR1, TLR2, TLR4, TLR6, and TLR10 were genotyped to describe their possible influence on T-regulatory cells required for keeping immune responses in balance and roles played in atopic diseases [50]. In neonates, the presence of AA genotype of the TLR2 promoter rs $4696480 \mathrm{SNP}$ associated with the increased expression of FOXP3 and Treg marker genes GITR and $L A G 3$, and also the secretion of TH2 cytokines and TNF- $\alpha$ in case of maternal atopy, with Tregs diminished without maternal atopy. The occurrence of GG genotype of TLR2 rs1898830 correlated with Treg marker genes decreasing with and increasing without maternal atopy [50]. The screening of common TLR2 (2258 G>A) and co-segregating TLR4 $(1063 \mathrm{~A}>\mathrm{G}$ and $1363 \mathrm{C}>\mathrm{T}) \mathrm{SNPs}$ in 94 women with preeclampsia and 176 healthy pregnancy controls showed the associations of these SNPs with early-onset but not lateonset preeclampsia [47]. Then, three TLR SNPs lowering thresholds for early-onset and severe pregnancy disease, but not late-onset or mild pregnancy disease, was described [47]. In turn, a study of 288 vaginal samples obtained from 144 women during both the first and second trimesters of pregnancy performed to determine the correlation of 34 SNPs residing in nine genes involved in TLR-mediated and related sensing and regulation of pathogens with the vaginal carriage of Gram-positive anaerobes Gardnerella vaginalis and Atopobium vaginae showed no association between gene polymorphisms and bacterial vaginosis (BV) [51]. No significant correlation was determined for TLR2 $-15607 \mathrm{~A}>\mathrm{G}$, $1350 \mathrm{~T}>\mathrm{C}, 2258 \mathrm{G}>\mathrm{A}$, and $2029 \mathrm{C}>\mathrm{T}$ SNPs [51]. The lack of a relationship between TLR2 polymorphisms and BV occurrence is consistent with the results of another study, performed to determine the influence of four TLR2 SNPs [rs18988
$(-15607 \mathrm{~A}>\mathrm{G})$, rs4696483, rs7656411, and rs1337)] on the cervical levels of pro- and anti-inflammatory cytokines and their association with BV [52]. In another study, analyses of the relevance of polymorphisms located in genes associated with innate immunity performed for a large cohort of preterm very-low-birth and term-born infants and their mothers showed no significant correlation between the presence of TLR2 2258G $>$ A SNP and the occurrence of intrauterine infections as the cause of preterm birth [53]. Another study also showed that comparable frequencies of the mutated $2258 \mathrm{G}$ allele of the TLR2 gene occurred in both pregnant women with preterm labor and healthy individuals [54]. In turn, another investigation reported that infants with two polymorphic TLR2 alleles (-16934TA/AA and 2258GA/AA) had, importantly, shorter gestational ages [55].

\section{SNPs in the TLR4 gene associated with pregnancy disorders}

For the TLR4 gene, $1063 \mathrm{~A}>\mathrm{G}$ and $1363 \mathrm{C}>\mathrm{T}$ SNPs were the most commonly studied. Real-time polymerase chain reaction (PCR) assays followed by high resolution melt (HRM) analysis, performed to simultaneously identify SNPs from TLR4 $(1063 \mathrm{~A}>\mathrm{G})$ as well as other genes $I L 6, I L 1 \beta$, and $I L 12 R B$ involved in the immune response showed no association of these polymorphisms with preterm birth of infants in Montevideo, Uruguay [48]. However, in the same population, fetuses carrying the $1063 \mathrm{~A}>\mathrm{G}$ SNP were both severely premature and had premature rupture of membranes (PROM) at the same time [56]. In a Canadian cohort which included mainly preterm infants, this TLR4 SNP occurred at a significantly lower frequency in infants without bronchopulmonary dysplasia (BPD) compared to those with diagnosed BPD. However, no significant association was observed between TLR4 genotypes and prematurity [57]. In turn, the research of a Finnish population showed the presence of the $1063 \mathrm{~A}>\mathrm{G}$ SNP in both infants and mothers and its correlation with preterm labor [58]. The frequency of TLR4 1063A/G alleles and their association with preterm labor might be populationspecific. It seems that further determination of the contribution of the $1063 \mathrm{~A}>\mathrm{G}$ SNP to preterm labor is required. In contrast to TLR2 polymorphisms, two SNPs located in the TLR4 sequence (rs1554973 or rs7856729) interacted significantly with $I L-1 R 2$ rs485127 and correlated with the concentration of IL$1 \beta$ in 188 African American and European American women [59]. The study showed both TLR4 and IL1-R2 genotypes as possible significant markers of cervical cytokines IL- $1 \alpha$ or IL$1 \beta$ concentrations and involvement in disparity in pregnancy outcomes. However, the observed associations were no longer significant after correction for multiple testing in European or African Americans [59]. An earlier study reported a genetic association between TLR4 rs1554973 and the level of cervical 
cytokine IL-1 $\beta$ characteristic for European but not African Americans, which was more significant in women with BV compared to those without BV [52]. These results are consistent with the observation that selection on TLRs varies between human populations [60]. In another study, the carriage of TLR4 rs1554973 SNP strongly associated with chorionic plate inflammation both in mothers and their singleton fetuses [61]. Four SNPs of TLR4 [1063A $>\mathrm{G}$ (rs4986790), 1363C $>\mathrm{T}$ (rs4986791), rs6478317, rs10759932] were reported to affect T-cell regulation [50]. Two common 1063A $>\mathrm{G}$ (rs4986790) and $1363 \mathrm{C}>\mathrm{T}$ TLR4 SNPs correlated with increased IL-13 secretion in core blood mononuclear cells (CBMC) obtained from umbilical veins after delivery and stimulated with Dermatophagoides pteronyssinus. CBMC with TLR4 rs6478317 (GG) had higher IL-12 secretion observed after stimulation with lipid A (LpA). 1063A >G (rs4986790) and 1363C $>$ T TLR4 SNPs were associated with a higher risk for atopic dermatitis [50]. Similarly to TLR2 SNPs, no TLR4 polymorphisms (rs1927914, 1063A $>\mathrm{G}, 1363 \mathrm{C}>\mathrm{T}$ ) were associated with BV in 288 vaginal samples obtained from 144 women during both the first and second trimesters of pregnancy [51]. However, another study showed that the $1063 \mathrm{~A}>\mathrm{G}$ SNP, disturbing response to LPS, was correlated with an increase in the vaginal $\mathrm{pH}$ and levels of Gardnerella vaginalis and anaerobic Gram-negative bacteria [62]. In a study of the occurrence of the $1363 \mathrm{C}>\mathrm{T}$ SNP in pregnant women with preterm labor and a control group, a lower frequency of heterozygous $\mathrm{CT}$ genotype and mutated $\mathrm{T}$ allele was observed in the study group [54]. Hence, this SNP might play a protective role against PROM in pregnant women. However, the proposed hypothesis has to be further investigated in a larger group of patients with PROM [54]. In Plasmodium falciparum-infected primiparous Ghanaian women, the $1063 \mathrm{~A}>\mathrm{G}$ SNP elevated the risk of low birth weight in term infants 6fold and the risk of maternal anemia 5-fold [63]. The obtained results suggested a correlation of the $1063 \mathrm{~A}>\mathrm{G}$ SNP with a clinical picture of malaria during pregnancy. However, this mutation did not associate with preterm labor [63], whereas the 1363C $>$ T SNP was, importantly, less common in women with BV compared with individuals without BV [64].

\section{SNPs in the TLR9 gene associated with diseases and ocular toxoplasmosis}

The accumulated data argued also for the association of different TLR9 SNPs with a variety of disorders, along with toxoplasmic retinochoroiditis, cervical cancer, mother-tochild transmission (MTCT) of human immunodeficiency virus type 1 (HIV-1), increased risk of low birth weight in infants, risk of maternal anemia, and a clinical picture of malaria in pregnancy $[49,63,65,66]$. The $1635 \mathrm{~A}>\mathrm{G}$ SNP residing in the TLR9 gene was reported to correlate with toxoplasmic retinochoroiditis in Brazil [49]. In the studied population, ocular toxoplasmosis was associated with allele $\mathrm{C}$ at $1635 \mathrm{~A}>\mathrm{G}$ [odds ratio (OR) 7; $95 \%$ confidence interval (CI) 1.6-30.8), which was at a frequency of $0.424 \%$, similar to that observed in European populations. The determined correlation suggested that direct interaction between $T$. gondii and TLR9 might trigger proinflammatory responses and, hence, led to severe pathologies such as ocular disease, associated with this infection in Brazil [49]. A study performed for the Polish population showed the association of TLR9 $1635 \mathrm{~A}>\mathrm{G}$ and also rs 187084 polymorphisms with cervical cancer and the possible significance of these SNPs as risk factors of cervical cancer development [65]. In turn, another work showed the role of the c.4-44G>A and c. $1635 \mathrm{~A}>\mathrm{G}$ SNPs in MTCT of HIV-1 [66]. While neither of the two SNPs were associated with a risk of HIV-1 infection, the $[\mathrm{G} ; \mathrm{G}]$ haplotype correlated with a higher risk of MTCT of HIV-1 after adjustment for maternal viral load [66]. A study performed for P. falciparum-infected primiparous Ghanaian women reported a correlation of the $-1486 \mathrm{~T}>\mathrm{C}$ SNP residing in the TLR9 gene, just as in the case of the $1063 \mathrm{~A}>\mathrm{G}$ SNP in the TLR4 gene, with an elevated risk of low birth weight in term infants and the risk of maternal anemia and, therefore, with a clinical picture of malaria in pregnancy [63].

\section{Concluding remarks}

It is important to investigate molecular mechanisms involved in Toxoplasma gondii congenital infections more precisely. It seems necessary to identify, in clinical specimens such as blood, amniotic fluid, cerebrospinal fluid, and the placenta, the genetic alterations of TLR2, TLR4, and $T L R 9$ genes accompanying the development of these infections and to describe the clinical significance of singlenucleotide polymorphisms (SNPs) residing in these genes in regard to congenital toxoplasmosis. TLR genes were suggested to play roles in toxoplasmosis development, progression of pregnancy, and various disorders of gestation. One possible modification influencing gene function, which was also confirmed in case of TLR2, TLR4, and TLR 9 genes in accordance to different diseases and pregnancy disorders, is the occurrence of SNPs within the genetic sequence. Therefore, the detailed description of the occurrence and the role of SNPs located in these three genes of the TLR family might pose a significant direction of research to determine new genetic alterations involved in immunity against $T$. gondii infections in pregnant women, their fetuses, and newborns.

Conflict of interest The authors declare that they have no conflict of interest. 
Open Access This article is distributed under the terms of the Creative Commons Attribution License which permits any use, distribution, and reproduction in any medium, provided the original author(s) and the source are credited.

\section{References}

1. Nowakowska D, Colón I, Remington JS, Grigg M, Golab E, Wilczyński J, Sibley LD (2006) Genotyping of Toxoplasma gondii by multiplex PCR and peptide-based serological testing of samples from infants in Poland diagnosed with congenital toxoplasmosis. J Clin Microbiol 44(4):1382-1389

2. Berrebi A, Bardou M, Bessieres MH, Nowakowska D, Castagno R, Rolland M, Wallon M, Franck J, Bongain A, MonnierBarbarino P, Assouline C, Cassaing S (2007) Outcome for children infected with congenital toxoplasmosis in the first trimester and with normal ultrasound findings: a study of 36 cases. Eur J Obstet Gynecol Reprod Biol 135(1):53-57

3. Jamieson SE, de Roubaix LA, Cortina-Borja M, Tan HK, Mui EJ, Cordell HJ, Kirisits MJ, Miller EN, Peacock CS, Hargrave AC, Coyne JJ, Boyer K, Bessieres MH, Buffolano W, Ferret N, Franck J, Kieffer F, Meier P, Nowakowska DE, Paul M, Peyron F, StrayPedersen B, Prusa AR, Thulliez P, Wallon M, Petersen E, McLeod R, Gilbert RE, Blackwell JM (2008) Genetic and epigenetic factors at COL2A1 and ABCA4 influence clinical outcome in congenital toxoplasmosis. PLoS One 3(6):e2285

4. Nowakowska D, Stray-Pedersen B, Spiewak E, Sobala W, Małafiej E, Wilczyński J (2006) Prevalence and estimated incidence of Toxoplasma infection among pregnant women in Poland: a decreasing trend in the younger population. Clin Microbiol Infect 12(9):913-917

5. Nowakowska D, Respondek-Liberska M, Golab E, Stray-Pedersen B, Szaflik K, Dzbenski TH, Wilczynski J (2005) Too late prenatal diagnosis of fetal toxoplasmosis: a case report. Fetal Diagn Ther 20 (3):190-193

6. Rajendran C, Su C, Dubey JP (2012) Molecular genotyping of Toxoplasma gondii from Central and South America revealed high diversity within and between populations. Infect Genet Evol 12 (2):359-368

7. Howe DK, Sibley LD (1995) Toxoplasma gondii comprises three clonal lineages: correlation of parasite genotype with human disease. J Infect Dis 172:1561-1566

8. Switaj K, Master A, Skrzypczak M, Zaborowski P (2005) Recent trends in molecular diagnostics for Toxoplasma gondii infections. Clin Microbiol Infect 11(3):170-176

9. Nathan CF, Murray HW, Wiebe ME, Rubin BY (1983) Identification of interferon-gamma as the lymphokine that activates human macrophage oxidative metabolism and antimicrobial activity. J Exp Med 158(3):670-689

10. Suzuki Y, Orellana MA, Schreiber RD, Remington JS (1988) Interferon-gamma: the major mediator of resistance against Toxoplasma gondii. Science 240(4851):516-518

11. Pifer R, Yarovinsky F (2011) Innate responses to Toxoplasma gondii in mice and humans. Trends Parasitol 27(9):388-393

12. Denkers EY, Butcher BA, Del Rio L, Bennouna S (2004) Neutrophils, dendritic cells and Toxoplasma. Int J Parasitol 34 (3):411-421

13. Yarovinsky F, Zhang D, Andersen JF, Bannenberg GL, Serhan CN, Hayden MS, Hieny S, Sutterwala FS, Flavell RA, Ghosh S, Sher A (2005) TLR11 activation of dendritic cells by a protozoan profilin-like protein. Science 308(5728):1626-1629

14. Yarovinsky F (2008) Toll-like receptors and their role in host resistance to Toxoplasma gondii. Immunol Lett 119(1-2):17-21
15. Roach JC, Glusman G, Rowen L, Kaur A, Purcell MK, Smith KD, Hood LE, Aderem A (2005) The evolution of vertebrate Toll-like receptors. Proc Natl Acad Sci U S A 102(27):9577-9582

16. McBerry C, Gonzalez RM, Shryock N, Dias A, Aliberti J (2012) SOCS2-induced proteasome-dependent TRAF6 degradation: a common anti-inflammatory pathway for control of innate immune responses. PLoS One 7(6): 38384

17. Liu CH, Machado FS, Guo R, Nichols KE, Burks AW, Aliberti JC, Zhong XP (2007) Diacylglycerol kinase zeta regulates microbial recognition and host resistance to Toxoplasma gondii. J Exp Med 204(4):781-792

18. Hou B, Benson A, Kuzmich L, DeFranco AL, Yarovinsky F (2011) Critical coordination of innate immune defense against Toxoplasma gondii by dendritic cells responding via their Tolllike receptors. Proc Natl Acad Sci U S A 108(1):278-283

19. Bierly AL, Shufesky WJ, Sukhumavasi W, Morelli AE, Denkers EY (2008) Dendritic cells expressing plasmacytoid marker PDCA-1 are Trojan horses during Toxoplasma gondii infection. J Immunol 181(12):8485-8491

20. Sukhumavasi W, Egan CE, Warren AL, Taylor GA, Fox BA, Bzik DJ, Denkers EY (2008) TLR adaptor MyD88 is essential for pathogen control during oral Toxoplasma gondii infection but not adaptive immunity induced by a vaccine strain of the parasite. $J$ Immunol 181(5):3464-3473

21. Melo MB, Kasperkovitz P, Cerny A, Könen-Waisman S, KurtJones EA, Lien E, Beutler B, Howard JC, Golenbock DT, Gazzinelli RT (2010) UNC93B1 mediates host resistance to infection with Toxoplasma gondii. PLoS Pathog 6(8):e1001071

22. Virta M, Pessi T, Helminen M, Seiskari T, Kondrashova A, Knip M, Hyöty H, Hurme M (2008) Interaction between CD14-159C $>\mathrm{T}$ polymorphism and Helicobacter pylori is associated with serum total immunoglobulin E. Clin Exp Allergy 38(12):1929-1934

23. Jones LA, Anthony JP, Henriquez FL, Lyons RE, Nickdel MB, Carter KC, Alexander J, Roberts CW (2008) Toll-like receptor-4mediated macrophage activation is differentially regulated by progesterone via the glucocorticoid and progesterone receptors. Immunology 125(1):59-69

24. Debierre-Grockiego F, Campos MA, Azzouz N, Schmidt J, Bieker U, Resende MG, Mansur DS, Weingart R, Schmidt RR, Golenbock DT, Gazzinelli RT, Schwarz RT (2007) Activation of TLR2 and TLR4 by glycosylphosphatidylinositols derived from Toxoplasma gondii. J Immunol 179(2):11291137

25. Benson A, Pifer R, Behrendt CL, Hooper LV, Yarovinsky F (2009) Gut commensal bacteria direct a protective immune response against Toxoplasma gondii. Cell Host Microbe 6 (2):187-196

26. Minns LA, Menard LC, Foureau DM, Darche S, Ronet C, Mielcarz DW, Buzoni-Gatel D, Kasper LH (2006) TLR9 is required for the gut-associated lymphoid tissue response following oral infection of Toxoplasma gondii. J Immunol 176(12):7589-7597

27. Degrandi D, Hoffmann R, Beuter-Gunia C, Pfeffer K (2009) The proinflammatory cytokine-induced IRG1 protein associates with mitochondria. J Interferon Cytokine Res 29(1):55-67

28. Mun HS, Aosai F, Norose K, Chen M, Piao LX, Takeuchi O, Akira S, Ishikura H, Yano A (2003) TLR2 as an essential molecule for protective immunity against Toxoplasma gondii infection. Int Immunol 15(9):1081-1087

29. Scharton-Kersten TM, Yap G, Magram J, Sher A (1997) Inducible nitric oxide is essential for host control of persistent but not acute infection with the intracellular pathogen Toxoplasma gondii. J Exp Med 185(7):1261-1273

30. Del Rio L, Butcher BA, Bennouna S, Hieny S, Sher A, Denkers EY (2004) Toxoplasma gondii triggers myeloid differentiation factor 88-dependent IL-12 and chemokine ligand 2 (monocyte 
chemoattractant protein 1) responses using distinct parasite molecules and host receptors. J Immunol 172(11):6954-6960

31. Makino M, Uemura N, Moroda M, Kikumura A, Piao LX, Mohamed RM, Aosai F (2011) Innate immunity in DNA vaccine with Toxoplasma gondil-heat shock protein 70 gene that induces DC activation and Th1 polarization. Vaccine 29 (10):1899-1905

32. Heimesaat MM, Fischer A, Jahn HK, Niebergall J, Freudenberg M, Blaut M, Liesenfeld O, Schumann RR, Göbel UB, Bereswill S (2007) Exacerbation of murine ileitis by Toll-like receptor 4 mediated sensing of lipopolysaccharide from commensal Escherichia coli. Gut 56(7):941-948

33. Denkers EY (2009) A gut feeling for microbes: getting it going between a parasite and its host. Cell Host Microbe 6(2):104-106

34. Schatz F, Kayisli UA, Vatandaslar E, Ocak N, Guller S, Abrahams VM, Krikun G, Lockwood CJ (2012) Toll-like receptor 4 expression in decidual cells and interstitial trophoblasts across human pregnancy. Am J Reprod Immunol 68(2):146-153

35. Gillaux C, Méhats C, Vaiman D, Cabrol D, Breuiller-Fouché M (2011) Functional screening of TLRs in human amniotic epithelial cells. J Immunol 187(5):2766-2774

36. Mitsunari M, Yoshida S, Shoji T, Tsukihara S, Iwabe T, Harada T, Terakawa N (2006) Macrophage-activating lipopeptide-2 induces cyclooxygenase-2 and prostaglandin $\mathrm{E}(2)$ via toll-like receptor 2 in human placental trophoblast cells. J Reprod Immunol 72(1-2):46-59

37. Abrahams VM, Bole-Aldo P, Kim YM, Straszewski-Chavez SL, Chaiworapongsa T, Romero R, Mor G (2004) Divergent trophoblast responses to bacterial products mediated by TLRs. J Immunol 173:4286-4296

38. Patni S, Wynen LP, Seager AL, Morgan G, White JO, Thornton CA (2009) Expression and activity of Toll-like receptors 1-9 in the human term placenta and changes associated with labor at term. Biol Reprod 80(2):243-248

39. Riley JK, Nelson DM (2010) Toll-like receptors in pregnancy disorders and placental dysfunction. Clin Rev Allergy Immunol 39(3):185-193

40. Koga K, Mor G (2010) Toll-like receptors at the maternal-fetal interface in normal pregnancy and pregnancy disorders. Am J Reprod Immunol 63(6):587-600

41. Rose JA, Rabenold JJ, Parast MM, Milstone DS, Abrahams VM, Riley JK (2011) Peptidoglycan induces necrosis and regulates cytokine production in murine trophoblast stem cells. Am J Reprod Immunol 66(3):209-222

42. Klaffenbach D, Friedrich D, Strick R, Strissel PL, Beckmann MW, Rascher W, Gessner A, Dötsch J, Meissner U, Schnare M (2011) Contribution of different placental cells to the expression and stimulation of antimicrobial proteins (AMPs). Placenta 32(11):830-837

43. Negishi M, Izumi Y, Aleemuzzaman S, Inaba N, Hayakawa S (2011) Lipopolysaccharide (LPS)-induced Interferon (IFN)-gamma production by decidual mononuclear cells (DMNC) is interleukin (IL)-2 and IL-12 dependent. Am J Reprod Immunol 65(1):20-27

44. Abrahams VM, Fahey JV, Schaefer TM, Wright JA, Wira CR, Mor G (2005) Stimulation of first trimester trophoblast cells with Poly (I:C) induces SLPI secretion. Am J Reprod Immunol 53:280

45. Beijar EC, Mallard C, Powell TL (2006) Expression and subcellular localization of TLR-4 in term and first trimester human placenta. Placenta 27(2-3):322-326

46. Gonzalez JM, Xu H, Ofori E, Elovitz MA (2007) Toll-like receptors in the uterus, cervix, and placenta: is pregnancy an immunosuppressed state? Am J Obstet Gynecol 197(3):296.e1-296.e6

47. Xie F, Hu Y, Speert DP, Turvey SE, Peng G, Money DM, Magee LA, von Dadelszen P; Toxaemia Study Group (2010) Toll-like receptor gene polymorphisms and preeclampsia risk: a case-control study and data synthesis. Hypertens Pregnancy 29(4):390-398
48. Pereyra S, Velazquez T, Bertoni B, Sapiro R (2012) Rapid multiplex high resolution melting method to analyze inflammatory related SNPs in preterm birth. BMC Res Notes 5:69

49. Peixoto-Rangel AL, Miller EN, Castellucci L, Jamieson SE, Peixe RG, Elias Lde S, Correa-Oliveira R, Bahia-Oliveira LM, Blackwell JM (2009) Candidate gene analysis of ocular toxoplasmosis in Brazil: evidence for a role for toll-like receptor 9 (TLR9). Mem Inst Oswaldo Cruz 104(8):1187-1190

50. Liu J, Rädler D, Illi S, Klucker E, Turan E, von Mutius E, Kabesch M, Schaub B (2011) TLR2 polymorphisms influence neonatal regulatory $\mathrm{T}$ cells depending on maternal atopy. Allergy 66:1020-1029

51. Verstraelen H, Verhelst R, Nuytinck L, Roelens K, De Meester E, De Vos D, Van Thielen M, Rossau R, Delva W, De Backer E, Vaneechoutte M, Temmerman M (2009) Gene polymorphisms of Toll-like and related recognition receptors in relation to the vaginal carriage of Gardnerella vaginalis and Atopobium vaginae. J Reprod Immunol 79(2):163-173

52. Ryckman KK, Williams SM, Krohn MA, Simhan HN (2009) Genetic association of Toll-like receptor 4 with cervical cytokine concentrations during pregnancy. Genes Immun 10(7):636-640

53. Härtel Ch, Finas D, Ahrens P, Kattner E, Schaible T, Müller D, Segerer H, Albrecht K, Möller J, Diedrich K, Göpel W; Genetic Factors in Neonatology Study Group (2004) Polymorphisms of genes involved in innate immunity: association with preterm delivery. Mol Hum Reprod 10(12):911-915

54. Łukaszewski T, Barlik M, Seremak-Mrozikiewicz A, Kurzawińska G, Mrozikiewicz PM, Sieroszewski P, Drews K (2009) Polymorphism in the genes of Toll-like receptors type 2 and type 4 (TLR-2 and $T L R-4)$ and the risk of premature rupture of the membranespreliminary study. Ginekol Pol 80(12):914-919

55. Krediet TG, Wiertsema SP, Vossers MJ, Hoeks SB, Fleer A, Ruven HJ, Rijkers GT (2007) Toll-like receptor 2 polymorphism is associated with preterm birth. Pediatr Res 62(4):474-476

56. Rey G, Skowronek F, Alciaturi J, Alonso J, Bertoni B, Sapiro R (2008) Toll receptor 4 Asp299Gly polymorphism and its association with preterm birth and premature rupture of membranes in a South American population. Mol Hum Reprod 14(9):555-559

57. Lavoie PM, Ladd M, Hirschfeld AF, Huusko J, Mahlman M, Speert DP, Hallman M, Lacaze-Masmonteil T, Turvey SE (2012) Influence of common non-synonymous Toll-like receptor 4 polymorphisms on bronchopulmonary dysplasia and prematurity in human infants. PLoS One 7(2):e31351

58. Lorenz E, Hallman M, Marttila R, Haataja R, Schwartz DA (2002) Association between the Asp299Gly polymorphisms in the Tolllike receptor 4 and premature births in the Finnish population. Pediatr Res 52(3):373-376

59. Ryckman KK, Williams SM, Krohn MA, Simhan HN (2011) Interaction between interleukin-1 receptor 2 and Toll-like receptor 4, and cervical cytokines. J Reprod Immunol 90(2):220-226

60. Barreiro LB, Ben-Ali M, Quach H, Laval G, Patin E, Pickrell JK, Bouchier C, Tichit M, Neyrolles O, Gicquel B, Kidd JR, Kidd KK, Alcaïs A, Ragimbeau J, Pellegrini S, Abel L, Casanova JL, Quintana-Murci L (2009) Evolutionary dynamics of human Tolllike receptors and their different contributions to host defense. PLoS Genet 5(7):e1000562

61. Simhan HN, MacPherson T, Caritis SN, Krohn MA (2008) Maternal and fetal Toll-like receptor 4 genotype and chorionic plate inflammatory lesions. Am J Obstet Gynecol 199(4):400.e1-400.e4

62. Bryant AE, Genc M, Hurtado RM, Chen KT (2004) Pulmonary Kaposi's sarcoma in pregnancy. Am J Perinatol 21(6):355-363

63. Mockenhaupt FP, Hamann L, von Gaertner C, Bedu-Addo G, von Kleinsorgen C, Schumann RR, Bienzle U (2006) Common polymorphisms of toll-like receptors 4 and 9 are associated with the clinical manifestation of malaria during pregnancy. J Infect Dis 194(2):184-188 
64. Goepfert AR, Varner M, Ward K, Macpherson C, Klebanoff M, Goldenberg RL, Mercer B, Meis P, Iams J, Moawad A, Carey JC, Leveno K, Wapner R, Caritis SN, Miodovnik M, Sorokin Y, O'Sullivan MJ, Van Dorsten JP, Langer O; NICHD MaternalFetal Medicine Units Network (2005) Differences in inflammatory cytokine and Toll-like receptor genes and bacterial vaginosis in pregnancy. Am J Obstet Gynecol 193(4):1478-1485
65. Roszak A, Lianeri M, Sowińska A, Jagodziński PP (2012) Involvement of Toll-like Receptor 9 polymorphism in cervical cancer development. Mol Biol Rep 39(8):8425-8430

66. Ricci E, Malacrida S, Zanchetta M, Mosconi I, Montagna M, Giaquinto C, De Rossi A (2010) Toll-like receptor 9 polymorphisms influence mother-to-child transmission of human immunodeficiency virus type 1 . J Transl Med 8:49 